\begin{tabular}{llcll}
\hline LEK. SIROV. & God. XXXIV & Broj 34 & Str. 69-80 & Beograd 2014. \\
LEK. SIROV. & Vol. XXXIV & No. 34 & Pp. 69-80 & Belgrade 2014. \\
\hline
\end{tabular}

Originalni naučni rad - Original scientific paper

Rukopis primljen: 2.6.2014.

UDC: $632.952: 665.528 ; 632.4$

Prihvaćen za publikovanje: 15.6.2014.

\title{
CHEMICAL COMPOSITION AND INHIBITORY ACTIVITY OF SELECTED ESSENTIAL OILS AGAINST FUNGI ISOLATED FROM MEDICINAL PLANTS
}

\section{Tatjana Stević1 ${ }^{1}$ Slaviša Stanković ${ }^{2}$, Katarina Šavikin ${ }^{1}$, Dejan Gođevac ${ }^{3}$, Ivica Dimkić ${ }^{2}$, Marina Soković ${ }^{4}$, Tanja Berić ${ }^{2}$}

\footnotetext{
${ }^{1}$ Institute for Medicinal Plants Research “Dr Josif Pančić”, Tadeuša Košćuška 1, 11000 Belgrade, Serbia

${ }^{2}$ Faculty of Biology, University of Belgrade, Studentski trg 16, 11000 Belgrade, Serbia

${ }^{3}$ Institute for Chemistry, Technology and Metallurgy, University of Belgrade, Njegoševa 12, 11000 Belgrade, Serbia

${ }^{4}$ Institute for Biological Research "Siniša Stanković", Bulevar Despota Stefana 142, 11000 Belgrade, Serbia
}

\begin{abstract}
In recent years great attention was paid to biological control, the application of natural products in order to protect crops and medicinal plants against contamination with phytopathogenic and saprophytic fungi. Essential oils have been evaluated as a potentially safe replacement for chemicals used for that purpose. In this regard, antifungal potential of six essential oils was examined coupled with determination of the complete qualitative and quantitative chemical composition by GC-FID and GC-MS analysis. While essential oils of rosemary, sage, Spanish sage and black pepper were exclusively composed of monoterpenes, vetiver essential oil was entirely composed of sesquiterpenes. In essential oil of cinnamon dominates (E)-cinnamaldehyde. Applying the in vitro microdilution method, it was found that all essential oils were active in inhibiting the growth of all tested 21 pre- and post-harvest phytopathogenic and saprophytic fungi. MIC and MFC ranged from $1.2 \mathrm{mg} \mathrm{m}^{-1}$ up to $22.6 \mathrm{mg}$ $\mathrm{ml}^{-1}$ according to the test oil. Rosemary oil showed the best antifungal potential, followed by black pepper and cinnamon oil. Sage and Spanish sage oils also exhibited significant antifungal potential. Vetiver oil demonstrated the lowest antifungal activity. Essential oils that showed considerable antifungal potential are good candidates for further examination of their use in preventing and/or protection of medicinal
\end{abstract}


plants, their seeds and dried drugs against fungal infections, both in the field and in warehouses.

Key words: Essential oils, antifungal activity, microdilution method, phytopathogenic and saprophytic fungi.

\section{INTRODUCTION}

The safety and quality of most agricultural crops and productsas well as medicinal plants and herbal drugs is constantly threatened, amongst other, with fungal infections leading to crop loses and post-harvest decay. Protection against phytopathogenic and saprophytic fungi encounters problems such as: increase of resistance to classical pesticides, the treatment costs, and the fact that most available antifungal drugs have only fungistatic activity [1]. Also, the usual antimicrobial chemicals used in agriculture for plant disease control (benzimidazoles, aromatic hydrocarbons and sterol biosynthesis inhibitors) are associated with series problems. Currently, there is a strong debate about the safety aspects of chemical preservatives since they are considered responsible for many carcinogenic and teratogenic attributes as well as residual toxicity [2]. All this creates a significant market opportunity for alternative products; natural biocontrol agents based on plantessential oils as alternative crop and medicinal plants protectants whose time has come [3]. Essential oils are naturally occurring phytochemicals which have various applications and have long been known and used throughout the world for treatment of many diseases, as well as to protect stored grain and legumes, and to repell insects in the home $[3,4]$. In general, plant-derived essential oils and extracts are considered as non-phytotoxic compounds and potentially effective against many fungal pathogens [5-7]. In addition, they have a broad spectrum of antifungal properties and they are environmentally friendly (biodegradable, do not leave toxic residues or byproducts to contaminate the environment) [8].

Six commercially available essential oils, differing in chemical composition, were evaluated as potential antifungal agents against number of phytopathogenic and saprophytic, pre-harvest and post-harvest fungi isolated from selected medicinal drugs (dried medicinal plant material).

\section{MATERIAL AND METHODS}

\section{Essential oils}

Following essential oils, all purchased from a Frey + Lau GmbH, HenstedtUlzburg, Germany, were used in this study: black pepper oil from Piper 
nigrum( $\mathrm{P} 0123085)$, cinnamon oil from Cinnamomum zeylonicum (P0125285), sage oil from Salvia officinalis (P0114240), spanish sage oil from Salvia lavandulaefolia (P0107205), rosemary oil from Rosmarinus officinalis (P0124476) and vetiver oil from Vetiveria zizanoides (P0114231).

\section{GC-FID and GC-MS analysis of the essential oils}

Gas chromatography-flame ionization detector (GC-FID) and Gas chromatography-mass spectrometry (GC-MS) analysis was performed on an Agilent 7890A GC equipped with 5975C inert XL EI/CI MSD and FID detector connected by capillary flow technology 2-way splitter with make-up. An HP-5 MSI capillary column $(30 \mathrm{~m} \times 0.25 \mathrm{~mm} \times 0.25 \mu \mathrm{m})$ was used. The temperature for GC oven was programmed from $60{ }^{\circ} \mathrm{C}$ to $300{ }^{\circ} \mathrm{C}$ at $3{ }^{\circ} \mathrm{C} \mathrm{min}^{-1}$ and hold for $10 \mathrm{~min}$. Helium was used as carrier gas at 16.255 psi (constant pressure mode). The sample was analyzed in the splitless mode. The injection volume was $1 \mu \mathrm{l}$. GC detector temperature was $300{ }^{\circ} \mathrm{C}$. MS data was acquired in EI mode, with scan range 30$550 \mathrm{~m} / \mathrm{z}$, source temperature was $230^{\circ} \mathrm{C}$ and quadrupole temperature was $150{ }^{\circ} \mathrm{C}$. Solvent delay was 3 minutes.

\section{Fungi tested}

Antifungal activity was tested on twenty one fungi which were isolated from selected herbal drugs and identified, as follows: Aspergillus flavus, Aspergillus niger, Alternaria alternata, Fusarium solani, Fusarium tricinctum, Fusarium sporotrichioides, Fusarium verticillioides, Fusarium oxysporum, Fusarium semitectum, Fusariumsubglutinans, Fusarium equiseti, Penicillium sp., Chaetomium sp., Gliocladium roseum, Curvularia lunata, Verticillium dahliae, Trichoderma viride, Trichotechium roseum,Phomopsis sp., Phoma sp. and Myrothechium verrucaria. As a source of isolation we used followingherbal drugs that showed the highest level of contamination by phytopathogenic and saprophytic fungi: mint folium et herb (Mentha piperita L.), nettle folium (Urtica dioica L.), marigold flowers (Calendula officinalis L.), horsetail herb (Equisetum arvense L.) and corn silk (maydis stigmata) [9].

\section{Antifungal assay in vitro}

To investigate antifungal activity of selected essential oils, a modified version of the microdilution technique was used [10,11]. Fungal spores were washed from the surface of malt agar (MA) plates (in $\mathrm{g}^{-1}$ : malt extract 50 and agar 15) with sterile $0.85 \%$ saline containing $0.1 \%$ Tween $80(\mathrm{v} / \mathrm{v})$. The spore suspension was adjusted with sterile saline to a concentration of approximately 1.0 $\times 10^{5} \mathrm{in}$ a final volume of $100 \mu \mathrm{l}$ per well. The inocula were stored at $4{ }^{\circ} \mathrm{C}$ for 
further use. Dilutions of the inocula were cultured on solid MA to verify the absence of contamination and to check the validity of the inoculum. Determination of MIC values was performed by a microdilution technique using 96-well microtiter plates. Tryptic Bile Soy Broth (TBS) (in $\mathrm{g}^{-1}$ : casein 20, bile salts 1.5 , $\mathrm{X}$-B-D glucuronic acid 0.075 and dimethyl sulfoxide 3 ) was used as the basis in the well to which was added $0.01 \%$ Tween 80 , different volumes of the investigated essential oils and fungal inoculum. The microplates were incubated for $72 \mathrm{~h}$ at 28 ${ }^{\circ} \mathrm{C}$. The lowest concentrations without visible growth were defined as the minimal concentrations which completely inhibited fungal growth (MIC). The minimal fungicidal concentrations (MFC) were determined by serial subcultivation of a $2 \mu 1$ volume on microtiter plates containing $100 \mu \mathrm{l}$ of broth per well and further incubation for $72 \mathrm{~h}$ at $28{ }^{\circ} \mathrm{C}$. The lowest concentration with no visible growth was defined as the MFC, indicating $99.5 \%$ killing of the original inoculum compared to fluconazole, used as a positive control.

\section{Statistical analysis}

Means separation of MIC was accomplished by Duncan's multiple range tests. Analysis of variance was performed on data of MIC and MFC of six oils on 21 pathogenic fungi. Significance was evaluated at $\mathrm{p}<0.05$ for all tests. Statistical analyses were conducted by the general procedures of STATISTICA v.7 (StatSoft, Inc.) and IBM SPSS Statistics v.20 (SPSS, Inc.).

\section{RESULTS AND DISCUSSION}

\section{Chemical composition of essential oils}

The components of the oil were identified by comparison of their mass spectra to those from Adams, Wiley 7, and NIST05 libraries. The identification was confirmed by retention time lock (RTL) method and RTL Adams Database. For quantification purpose, area percent data obtained by FID were used. The number of identified compounds in each essential oil studied in this work ranged between 19 and 32, comprising $72.20-99.88 \%$ of the total essential oil volatile compounds (Table 1). 
Table 1.Chemical composition (\%)of essential oils by GC-FID and GC-MS

Tabela 1.Hemijski sastav (\%)etarskih ulja određen GC-FID i GC-MS analizom

\begin{tabular}{|c|c|c|c|c|c|c|c|}
\hline Compound & RI & Sp.sage & Sage & Rosemary & Bl.pepper & Vetiver & Cinnamon \\
\hline \multicolumn{2}{|c|}{ Monoterpenehydrocarbons } & 39.59 & 20.28 & 27.49 & 69.89 & $\mathbf{0}$ & 3.91 \\
\hline$\alpha$-Pinene & 919 & 17.14 & 6.65 & 10.30 & 15.49 & - & 0.73 \\
\hline Camphene & 938 & 4.62 & 7.11 & 4.44 & 0.39 & - & trace \\
\hline Sabinene & 969 & 0.24 & 0.67 & 0.05 & 5.48 & - & - \\
\hline$\beta$-Pinene & 975 & 2.46 & 1.79 & 7.86 & 14.87 & - & 0.16 \\
\hline Myrcene & 991 & 0.91 & trace & 0.92 & 1.06 & - & - \\
\hline$\alpha$-Phellandrene & 1006 & - & - & 0.13 & 2.84 & - & - \\
\hline 3-Carene & 1010 & - & - & 0.11 & 9.54 & - & - \\
\hline$p$-Cymene & 1024 & 0.34 & 0.78 & 1.00 & 1.47 & - & 1.30 \\
\hline Limonene & 1030 & 13.88 & 3.28 & 2.68 & 18.75 & - & 1.72 \\
\hline \multicolumn{2}{|c|}{ Oxygenated monoterpenes } & 55.31 & 53.09 & 64.2 & 1.68 & $\mathbf{0}$ & 9.03 \\
\hline 1,8-Cineole & 1031 & 10.56 & 13.95 & 45.34 & trace & - & 2.22 \\
\hline Linalool & 1094 & 0.63 & 1.00 & 0.56 & 0.62 & - & 3.70 \\
\hline cis-Thujone & 1103 & - & 28.54 & - & - & - & - \\
\hline trans-Thujone & 1112 & - & 2.54 & - & - & - & - \\
\hline Camphor & 1142 & 26.64 & - & 13.00 & - & - & - \\
\hline Borneol & 1164 & 7.14 & 3.52 & 2.54 & - & - & - \\
\hline$\alpha$-Terpineol & 1160 & 2.31 & 1.34 & 1.68 & 0.06 & - & 0.98 \\
\hline Piperitenone & 1255 & - & - & - & 1.00 & - & - \\
\hline Linalool acetate & 1259 & 3.09 & - & - & - & - & - \\
\hline Bornyl acetate & 1288 & 4.94 & 2.20 & 1.08 & - & - & 2.13 \\
\hline Thymol & 1293 & - & - & - & - & - & - \\
\hline \multicolumn{2}{|c|}{ Sesquiterp.hydrocarbons } & 0.21 & 2.31 & 4.48 & 21.3 & 5.71 & 2.60 \\
\hline$\alpha$-Copaene & 1378 & - & - & - & 1.86 & - & - \\
\hline (E)-Caryophyllene & 1422 & 0.21 & 2.31 & 4.48 & 19.44 & - & 2.60 \\
\hline$\alpha$-Amorphene & 1485 & - & - & - & - & 1.78 & - \\
\hline$\beta$-Vetispirene & 1495 & - & - & - & - & 1.72 & - \\
\hline$\beta$-Vetivenene & 1557 & - & - & - & - & 2.21 & - \\
\hline \multicolumn{2}{|c|}{ Oxygenated sesquiterpenes } & $\mathbf{0}$ & 0 & $\mathbf{0}$ & $\mathbf{0}$ & 59.82 & $\mathbf{0}$ \\
\hline Junenol & 1621 & - & - & - & - & 3.57 & - \\
\hline 10-epi- $\gamma$-Eudesmol & 1625 & - & - & - & - & 3.01 & - \\
\hline Valerianol & 1658 & - & - & - & - & 3.12 & - \\
\hline 7-epi- $\alpha$-Eudesmol & 1663 & - & - & - & - & 1.71 & - \\
\hline Guaiol acetate & 1719 & - & - & - & - & 1.45 & - \\
\hline Vetiselinenol & 1728 & - & - & - & - & 4.52 & - \\
\hline Khusimol & 1748 & - & - & - & - & 18.22 & - \\
\hline (E)-Isovalencenol & 1794 & - & - & - & - & 14.67 & - \\
\hline$\beta$-Vetivone & 1823 & - & - & - & - & 4.13 & - \\
\hline$\alpha$-Vetivone & 1847 & - & - & - & - & 5.42 & - \\
\hline Others & & $\mathbf{0}$ & $\mathbf{0}$ & $\mathbf{0}$ & $\mathbf{0}$ & $\mathbf{0}$ & 82.67 \\
\hline (E)-Cinnamaldehyde & 1276 & - & - & - & - & - & 74.04 \\
\hline Eugenol & 1359 & - & - & - & - & - & 3.08 \\
\hline Cinnamyl acetate & 1447 & - & - & - & - & - & 5.55 \\
\hline \multicolumn{2}{|c|}{ Total identified (\%) } & 95.11 & 75.68 & 96.17 & 92.87 & 65.53 & 98.21 \\
\hline \multicolumn{2}{|c|}{ No. of comp. identified } & $15(27)$ & $14(25)$ & $16(29)$ & $15(32)$ & $13(24)$ & $13(19)$ \\
\hline
\end{tabular}

*Listed copmounds show a min. concentr.of $1 \%$ in at least one oil analyzed. RI - retention index 
The essential oils of Spanish sage and rosemary were characterized by domination of monoterpenes, representing as high as $94.90 \%$ and $91.69 \%$, respectively. High content of monoterpenes was also detected in the sage oil (73.37 $\%)$ and the black pepper oil (71.57\%). Regarding ratio of monoterpene hydrocarbons and oxygenated monoterpenes, while the Spanish sage oil was represented with almost equal quantity of both (Table 1), the black pepper oil was dominated with monoterpene hydrocarbons. In case of the sage and rosemary oils, oxygenated monoterpenes prevailed. On the other hand, vetiver oil was characterized with total absence of monoterpenes and with sesquiterpenes content above $65 \%$. Content of oxygenated sesquiterpenes reached $59.82 \%$ while sesquiterpene hydrocarbons were present in the oil with only $5.71 \%$. The cinnamon oil was distinct from all other oils with absolute predominance of just one compound, aromatic aldehyde, (E)-cinnamaldehyde (74\%).

The essential oil of Spanish sage was characterize by relatively high content of camphor $(26.64 \%)$ followed by $\alpha$-pinene $(17.14 \%)$, limonene $(13.88$ $\%)$ and 1,8-cineole (10.56\%), similarly to already reported oil composition [12]. Sage oil was of cis-thujone chemotype, represented with $28.54 \%$ of cis-thujone and $13.95 \%$ of 1,8-cineole, comparable with composition of the sage oils from Lithuania [13], althought with considerably higher percentage of both, cis-thujone and 1,8-cineole. Lower quantity of camphene (7.11\%) and $\alpha$-pinene $(6.65 \%)$ were also detected in the sage oil. The rosemary oil was characterized with high percentage of 1,8-cineole (45.34\%), as a main compound, followed by camphor (13\%), $\alpha$-pinene $(10.30 \%)$ and $\beta$-pinene (7.86\%). Previous studies found similar chemical composition of the oil with different percentage of the most abundant compounds, although not so high content of 1,8-cineole as in our oil sample $[14,15]$. The black pepper oil showed similar quantity of (E)-caryophyllene (19.44 $\%)$, limonene $(18.75 \%), \alpha$-pinene $(15.49 \%)$ and $\beta$-pinene $(14.87 \%)$ as the ones reported by Menon et al. [16]. The essential oil of vetiver was particularly rich in oxygenated sesquiterpenes, with only two compounds present in considerable amount, khusimol (18.22\%) and (E)-isovalencenol (14.67\%), followed by less content of $\alpha$ - and $\beta$-vetivone (5.42\% and $4.13 \%$, respectively) and a number of less known sesquiterpenes present in small percentage (Table 1). The characteristic constituents of vetiver oils from nine different geographical origins, described by Champagnatet al. [17] were $\beta$-vetispirene, khusimol, vetiselinenol and $\alpha$-vetivone, confirming the relative homogeneity of vetiver oil by the content of its major constituents. Apart from cinnamaldehyde (74\%) and related cinnamyl acetate (5.50 $\%)$, there was no considerable amount of any other compound in essential oil of cinnamon, as it is common for cinnamon oil $[18,19]$. 


\section{Antifungal activity of essential oils}

Previously isolated and identified 21 fungi from plant drugs [9] were used for testing antifungal activity of selected essential oils. Results of microdilution assay are presented in Table 2. Antifungal activity was recorded for all oils against all fungi tested. MIC and MFC ranged from $1.2 \mathrm{mg} \mathrm{ml}^{-1}$ up to $22.6 \mathrm{mg} \mathrm{m}^{-1}$. The best potential in inhibiting fungal growth was detected for rosemary oil (MIC from 1.2 to $5.6 \mathrm{mg} \mathrm{ml}^{-1}$ ). For 14, out of 21 fungi tested, lowest MICwas recorded when rosemary oil was used. Lower inhibitory concentration, although below $10 \mathrm{mg} \mathrm{ml}^{-1}$ for all fungi tested, exhibited both, the black pepper and cinnamon oils, regardless their completely different composition, as well as the sage oil (except for $F$. tricinctum, where MIC, and MFC were above $10 \mathrm{mg} \mathrm{ml}^{-1}$ ). Lower potential for antifungal activity, compared to previously mentioned three oils, was noted for the Spanish sage oil, with MIC range from 5.6 to $14.7 \mathrm{mg} \mathrm{ml}^{-1}$. Highest MIC values and consequently lowest inhibitory potential was exhibited by the vetiver oil. For half of tested fungi more than $15 \mathrm{mg} \mathrm{ml}^{-1}$ of this oil was necessary for inhibition of visible growth. Antifungal activity of the rosemary and cinnamon oils could be easily atributed to oxygenated monoterpenes, 1,8-cineole and cinnamaldehyde, respectively, due to their high percentage shares and already demonstrated antifungal potential [20,21]. Addressing antifungal activity to particular compounds is difficult when oils are with small share of many constituents, which was the case with all of the rest oils studied here. Nevertheless, merit for potential in inhibiting fungal growth of our both sage oils can be probably attributed to oxygenated monoterpenes, cis-thujone [22] and 1,8-cineole (for the sage oil), and camphor, 1,8-cineole and borneol (for the Spanish sage oil). The essential oil of Lavandula pedunculata(Miller)with its highest content of camphor was the most active against dermatophyte strains [23]. Recent results of study on (-)-borneol indicate its antifungal actions against Aspergillus fumigatus and Epidermophyton floccosum with more fungicidal than fungistatic activity by in vitro assays and morphological observations [24]. On the other hand, poor antifungal potential of the black peppers oil, most likely resulted from already proven activity of (E)caryophyllene [25]in addition to its combination with $\alpha$ - and $\beta$-pinene. It has been reported for $\alpha$-pinene from oils from Pistacia lentiscus to possess antifungal activity [26], as for both, $\alpha$ - and $\beta$-pinene, from different pines essential oils [27].

Parallel with obtaining of MIC, MFC were also determined for all oils against all fungi tested (Table 2). For nearly half tested combinations, MFC values were exactly the same as the MIC values, and for the rest of them, with a few exceptions, MFC was very close to the value of MIC. These results indicate fungicidal activity of the tested oils.

Taking results altogether, the most sensitive fungal species to tested essential oils were $M$. verrucaria, $V$. dahlia and $A$. niger. On the other hand, highest MIC values were required for inhibition of $T$. viridae, F. subglutinans and A.flavus. 


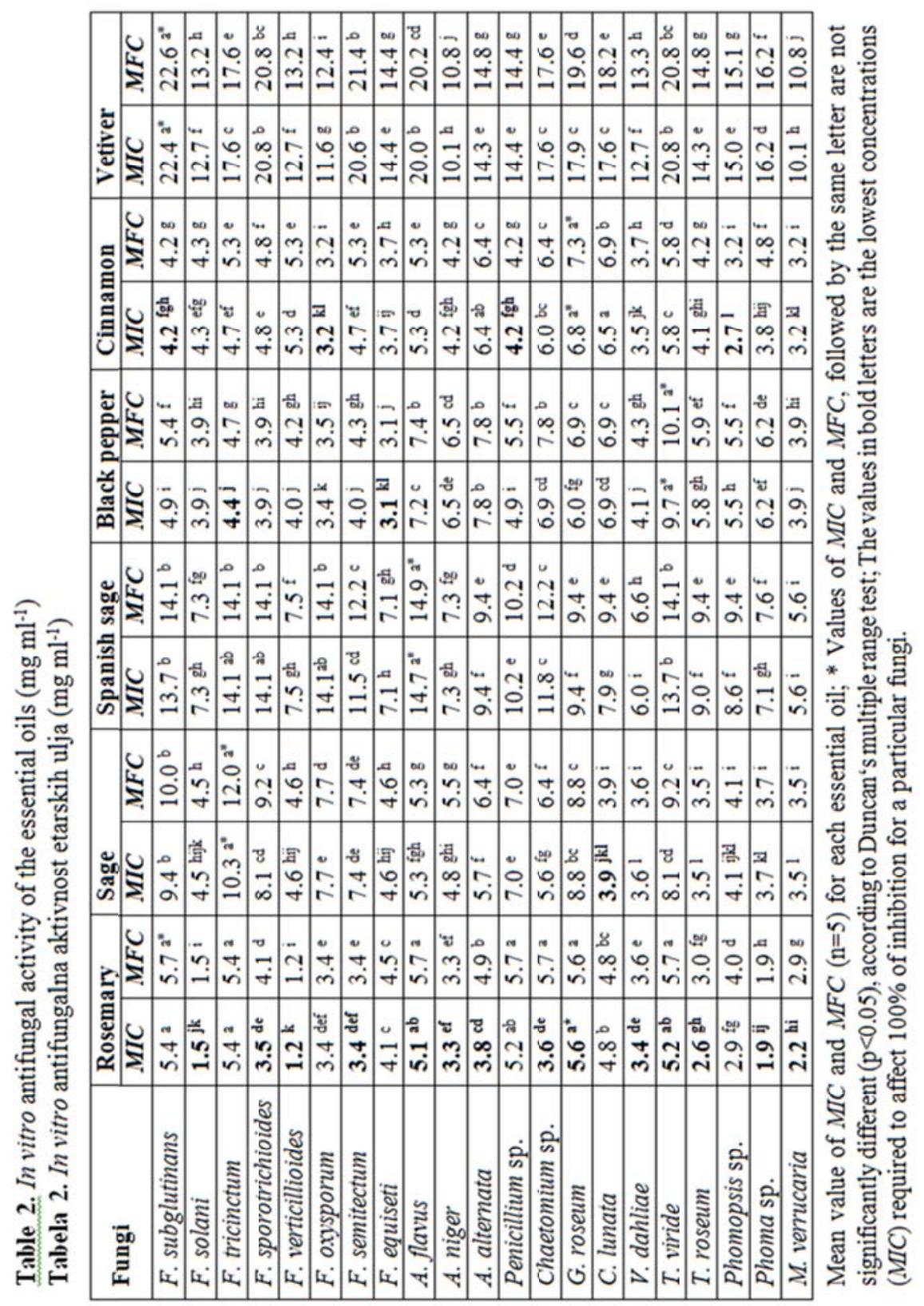




\section{CONCLUSIONS}

In conclusion, all six essential oils tested in vitro,exhibited antifungal activity against all fungi tested, with various degree of efficacy. The monoterpene containing essential oil (sage oil, Spanish sage oil, rosemary oil and black paper oil) were superior to the sesquiterpene dominated vetiver oil in inhibiting fungal growth. Results indicate fungicidal activity of six tested essential oils which can be used in control of a number of fungi. Further testing of the oils, especially the rosemary, cinnamon and black pepper, should be conducetd in situ conditions for determination of their potential in protection and/or prevention of various seeds and crops against fungal infection, both in the field and in the warehouses.

\section{ACKNOWLEDGEMENTS}

This work was supported by the Ministry of Education, Science and Technological Development, Republic of Serbia (Grants No. III46013 and OI173026).

\section{REFERENCES}

1. R.P. Rapp (2004): Changing strategies for the management of invasive fungal infections, Pharmacotherapy, vol.24, 4S-28S.

2. P. Skandamis, K. Koutsoumanis, K. Fasseas, G.J.E. Nychas (2001): Inhibition of oregano essential oil and EDTA on E. coli O157:H7,Ital. J. Food Sci., vol. $13,55-65$.

3. B.M. Isman (2000): Plant essential oils for pest and disease management, Crop Prot., vol. 19, 603-608.

4. N. Tabassum, Vidysagar G.M. (2013): Antifungal investigations on plant essential oils. A review, Int. J. Pharm. Pharm. Sci.,vol. 5(2), 19-28.

5. D. Kalemba, A. Kunicka (2003): Antibacterial and antifungal properties of essential oils, Curr. Med. Chem., vol. 10, 813-829.

6. J.G. Lopez-Reyes, D. Spadaro, A. Prelle, A. Garibaldi, M.L. Gullino (2013): Efficacy of plant essential oils on postharvest control of rots by fungi on different stone fruits in vivo, J. Food Prot., vol. 76(4): 631-639.

7. H. Bouzenna, L. Krichen (2013): Pelargonium graveolens L'Her. andArtemisia arborescens L. essential oils: Chemical composition, antifungal activity against Rhizoctonia solani and insecticidal activity against Rhysopertha dominica, Nat. Prod. Res., vol.27(9): 841-846. 
8. M. Abdel-Kader, N. El-Mougy, S. Lashin (2011): Essential oils and Trichoderma harzianum as an integrated control measure against faba bean root pathogens, J. Plant Prot. Res., vol. 51(3): 306313.

9. T. Stević, S. Pavlović, S. Stanković, K. Šavikin (2012): Pathogenic microorganisms of medicinal herbal drugs, Arch. Biol. Sci., vol. 64(1): 49-58.

10. H. Hanel, W. Raether (1988): A more sophisticated method of determining the fungicidal effect of water-insoluble preparations with a cell harvester, using miconazole as an example, Mycoses, vol. 31, 148-154.

11. R. Daouk, H. Dagher, J. Sattout (1995): Antifungal activity of the essential oil of Origanum syriacum L., J. Food Protect.,vol. 58, 1147-1149.

12. N.S.L. Perry, P.J. Houghton, A. Theobald, P. Jenner, E.K. Perry (2000): Invitro inhibition of human erythrocyte acetylcholinesterase by Salvia lavandulaefolia essential oil and constituent terpenes, J. Pharm. Pharmacol., vol. 52, 895-902.

13. D. Mockuté, D., O. Nivinskiené, G. Bernotiené, R. Butkiené (2003): The cisthujone chemotype of Salvia officinalis L. essential oils, Chemija (Vilnius), vol. 14(4): 216-220.

14. Y. Jiang, N. Wu, Y-J. Fu, W. Wang, M. Luo, C.J. Zhao et al. (2011): Chemical composition and antimicrobial activity of the essential oil of Rosemary, Environ. Toxicol. Pharmacol, vol. 32, 63-68.

15. D. Lakušić, M. Ristić, V. Slakovska, Lakušić (2013): Seasonal variations in the composition of the essential oils of rosemary (Rosmarinus officinalis, Lamiaceae), Nat. Prod. Commun, vol. 8, 131-134.

16. A.N. Menon, K.P. Padmakumari, A. Jayalekshmy, M. Gopalakrishnan, C.S. Narayanan (2000): Essential Oil Composition of Four Popular Indian Cultivars of Black Pepper (Piper nigrum L.), J. Essent. Oil Res.,vol. 12, 431-434.

17. P. Champagnat, G. Figueredo, J.C. Chalchat, A.P. Carnat, J.M. Bessibre (2006): A study on the composition of commercial Vetiveria zizanioldes oils from different geographical origins, J. Essent. Oil Res., vol. 18, 416-422.

18. Tomaino, F. Cimino, V. Zimbalati, Venuti Enuti, V., Sulfaro, V., De Pasquale, A. et al. (2005): "Influence of heating on antioxidant activity and the chemical composition of some spice essential oils", Food Chem., vol. 89, 549-554.

19. G. Singh, S. Maurya, M.P. DeLampasona, C.A.N. Catalan (2007): A comparison of chemical, antioxidant and antimicrobial studies of cinnamon leaf and bark volatile oils, oleoresins and their constituents, Food Chem. Toxicol., vol. 45, 1650-1661.

20. L. S. M. Ooi, , Y.L. Li, , S.L. Kam, H. Wang, E. Y. L. Wong, V. E. C. Ooi (2006): Antimicrobial activities of cinnamon oil and cinnamaldehyde from the Chinese medicinal herb Cinnamomum cassia, Blume, Am. J. Chin. Med., vol. $34,511-522$. 
21. G.R. Vilela, G.S. De Almeida, M.A. D'Arce, M.H.D. Moraes, , J.O. Brito, M.F. Da Silva, et al. (2009): Activity of essential oil and its major compound, 1,8-cineole, from Eucalyptus globulus Labill., against the storage fungi, Aspergillus flavus Link and Aspergillus parasiticus Speare, J. Stored Prod. Res., vol. 45, 108-111.

22. D. Pitarokili, O. Tzakou, M. Couladis, E. Verykokidou (1999): Composition and antifungal activity of the essential oil of Salvia pomifera subsp. calycina growing wild in Greece, J. Essential Oil Res.,vol. 11, 655-659.

23. M. Zuzarte, M., M.J. Goncalves, C. Cavaleiro, A.M. Dinis, J. Canhoto, L. Salgueiro (2009): Chemical composition and antifungal activity of the essential oils of Lavandulapedunculata (Miller), Cav. Chem. Biodivers., vol. 6, 1283-92.

24. S.Y. Lee, S.H. Kim, C.Y. Hong, M-J Park, I-G.Choi (2013): Effects of (-)-borneol on the growth and morphology of Aspergillus fumigatus and Epidermophyton floccosom, Flavor Frag. J., vol.28(2): 129-134.

25. F. Deba, T.D. Xuan, M. Yasuda, S. Tawata (2008): Chemical composition and antioxidant, antibacterial and antifungal activities of the essential oils from Bidens pilosa Linn. var. radiate, Food Control,vol. 19, 346-352.

26. P. Magiatis, E. Melliou, A.L. Skaltsounis, I.B. Chinou, S. Mitaku (1999): Chemical composition and antimicrobial activity of the essential oils of Pistacia lentiscus var. chia, Planta Medica,vol. 65, 749-752.

27. M. Krauze-Baranowska, M. Mardarowicz, M. Wiwart, L. Poblocka, M. Dynowska (2002): Antifungal activity of the essential oils from some species of the genus Pinus, Verlag der Zeitschrift fur Naturforschung, vol. 57c, 478-482. 


\section{HEMIJSKI SASTAV I INHIBITORNA AKTIVNOST ODABRANIH ETARSKIH ULJA NA GLJIVE IZOLOVANE SA LEKOVITOG BILJA}

\section{Tatjana Stević ${ }^{1}$, Slaviša Stanković ${ }^{2}$, Katarina Šavikin ${ }^{1}$, Dejan Gođevac ${ }^{3}$, Ivica Dimkić ${ }^{2}$, Marina Soković ${ }^{4}$, Tanja Berić ${ }^{2}$}

\footnotetext{
${ }^{1}$ Institut za proučavanje lekovitog bilja „Dr Josif Pančić““, Tadeuša Košćuška 1, 11000 Beograd, Srbia

${ }^{2}$ Biološki Fakultet, Univerzitet u Beogradu, Studentski trg 16, 11000 Beograd, Srbija

${ }^{3}$ Institut za hemiju, tehnologiju i metalurgju, Univerzitet u Beogradu, Njegoševa 12, 11000 Beograd, Srbija

${ }^{4}$ Institut za biološka istraživanja "Siniša Stanković”, Bulevar Despota Stefana 142, 11000 Beograd, Srbija
}

\section{IZVOD}

Poslednjih godina velika pažnja poklanja se biološkoj kontroli to jest primeni prirodnih produkata u zaštiti, kako poljoprivrednih kultura, tako i lekovitog bilja od kontaminacije fitopatogenim i saprofitnim gljivama. U tom smislu, ispitivan je antifungalni potencijal šest etarskih ulja uz određivanje kompletnog kvalitativnog i kvantitativnog hemijskog sastava primenom GC-FID i GC-MS analiza. Dok se korišćeni uzorci etarskih ulja ruzmarina, žalfije, španske žalfije i crnog bibera isključivo sastoje od monoterpena, u ulju vetivera potpuno dominiraju seskviterpeni. U etarskom ulju cimeta najzastupljenija komponneta je bila (E)cinemaldehid. Primenom in vitro mikrodilucione metode, utvrđeno je da su sva ulja bila aktivna $u$ inhibiciji rasta 21 testirane, pre- i post-žetvene, fitopatogene i saprofitne gljive, sa razlikama u efikasnosti. MIC i MFC vrednosti su varirale u opsegu od 1,2 $\mathrm{mg} \mathrm{ml}^{-1}$ do $22,6 \mathrm{mg} \mathrm{ml}^{-1}$, u zavisnosti od ispitivanog ulja. Najbolja antifungalna aktivnost utvrđena je za ulje ruzmarina, nešto slabija za ulja crnog bibera i cimeta, dok je ulje vetivera ispoljilo najslabiju aktivnost. Etarska ulja obe vrste žalfija ispoljila su značajan antifungalni potencijal. Etarska ulja koja poseduju značajan antifungalni potencijal su dobri kandidati za nastavak istraživanja u pravcu njihove primene u prevenciji i zaštiti useva lekovitog bilja, kao i njihovih semena i osušenih biljnih droga od gljivičnih infekcija, i u polju i u skladištima.

Ključne reči: Etarska ulja, antifungalna aktivnost, mikrodilucioni metod, fitopatogene i saprofitne gljive, lekovito bilje. 